\title{
Effect of Non-Genetic Factors on Test-Day Milk Yields and First Lactation Milk Yields in Holstein Friesian $\times$ Sahiwal Cattle
}

\author{
Rohit Gupta $^{1}$, Saroj Kumar Sahoo ${ }^{2 *}$, Simarjeet Kaur ${ }^{2}$, Shakti Kant Dash ${ }^{2}$, \\ Puneet Malhotra ${ }^{2}$ and Baljinder Kumar Bansal ${ }^{2}$ \\ ${ }^{1}$ Department of Animal Genetics and Breeding, Guru Angad Dev Veterinary and Animal Sciences University, Ludhiana, INDIA \\ ${ }^{2}$ Directorate of Livestock Farms, Guru Angad Dev Veterinary and Animal Sciences, University, Ludhiana, INDIA
}

"Corresponding author: SK Sahoo; E-mail: saroj6804@gmail.com

Received: 14 Feb., 2020

Revised: 29 April, 2020

Accepted: 04 May, 2020

\begin{abstract}
The present study was carried out using first lactation monthly test-day milk yield records of 466 crossbred (HF $\times$ Sahiwal) cattle calved from 2000 to 2018 sired by 89 bulls maintained at Directorate of Livestock Farms, GADVASU, Ludhiana. Mixed model analysis was carried out by least-squares maximum likelihood programme to study the effects of non-genetic factors on first full lactation milk yield (FFLMY), first lactation 305-day milk yield (FL305MY) and monthly test-day (TD) milk yield records of crossbred cattle. The least squares means of different monthly TD milk yields ( $1^{\text {st }}$ to $\left.11^{\text {th }}\right)$ were $12.05 \pm 0.42,15.65 \pm$ $0.42,15.38 \pm 0.44,14.44 \pm 0.43,13.79 \pm 0.41,12.88 \pm 0.40,12.27 \pm 0.42,11.83 \pm 0.37,10.85 \pm 0.42,10.64 \pm 0.45$ and 10.28 $\pm 0.50 \mathrm{~kg}$, respectively. For FFLMY and FL305MY the means were $4979.60 \pm 184.45$ and $3818.17 \pm 103.26 \mathrm{~kg}$. The effects of different AFC groups were non-significant on TDs and FL305MYs, whereas it was significant ( $\mathrm{p} \leq 0.01)$ for FFLMY. The season was significant $(\mathrm{p} \leq 0.01)$ for all the monthly TDs whereas it was non-significant for FFLMY and FL305MY. The sire was significant ( $\mathrm{p} \leq 0.01)$ for most of the TDs and FL305MYs except the later TDs $\left(9^{\text {th }}, 10^{\text {th }}\right.$ and $11^{\text {th }}$ TD) and FFLMYs. The present investigation revealed the importance of non-genetic factors in performance evaluation of crossbred cattle based on monthly test-day milk yield, FL305MY and FFLMY records.
\end{abstract}

Keywords: Crossbred cattle, test day milk yield, non-genetic factors

Milk production is one of the most important economic traits in dairy cattle. Improving milk productivity of Indian cow has been pursued since many decades in India. It is conceded that average yield of an Indian cow is very low, at about 1000 litre/lactation (Dohare et al., 2014). Cross breeding with exotic European breeds are the best alternative to improve the genotype and milk producing capability of the low yielding Indian cows.

With only 17.67 percent of total bovine population, crossbred cattle contributes 26 per cent of the total milk production in India (BAHS, 2019). During 2018-19, the average milk yield per exotic/crossbred cattle in Punjab $(13.43 \mathrm{~kg} /$ day $)$ was far above the national average (7.95 $\mathrm{kg}$ /day) which describes the importance of crossbred cattle in India and Punjab, in particular.
The main objective of any breed improvement program is to bring about genetic progress by selection of superior sires and dams. The sires are genetically evaluated on the basis of first lactation 305-day milk yield of their daughters at organized farms. The test-day milk yield model accounts for environmental variation specific to individual test-day milk yields and genetic effects associated with individual animals. The estimation of effects of non-genetic parameters on test-day and full lactation milk yields are helpful in predicting selection responses and can be used for further refinement of breeding programmes for overall

How to cite this article: Gupta, R., Sahoo, S.K., Kaur, S., Dash, S.K. Malhotra, P. and Bansal, B.K. (2020). Effect of non-genetic factors on test-day milk yields and first lactation milk yields in Holstein Friesian $\times$ Sahiwal cattle. J. Anim. Res., 10(3): 447-451.

Source of Support: None; Conflict of Interest: None 
improvement and genetic gains in organized farms. Accordingly, the present study was done to see the effect of non-genetic factors on first lactation milk yields of crossbred cattle $(\mathrm{HF} \times$ Sahiwal) maintained at Directorate of Livestock Farms, Guru Angad Dev Veterinary and Animal Sciences University (GADVASU), Ludhiana.

\section{MATERIALS AND METHODS}

The study was conducted on first lactation monthly testday milk yield records (4415 Nos.) of 466 crossbred (CB) cattle sired by 89 bulls maintained during 2000 - 2018 (19 years) at Directorate of Livestock Farms, GADVASU, Ludhiana. The crossbred cattle with minimum lactation length of 100 days were considered for the study.

\section{Classification of data}

The data were classified and coded according to different season of calving and age at first calving groups for first full lactation milk yield (FFLMY), first lactation 305-day milk yield (FL305MY) and monthly test-day (TD) milk yield records of crossbred cattle.

\section{Season of calving}

Season was considered to be one of the main factors of the environment that affects the performance of cattle. There is a wide variation of climatic conditions throughout the year, differences are being more between the seasons and less within a season. Thus, the year was divided into four seasons on the basis of rainfall, temperature and humidity over the years as S-1 (Winter: November to February), S-2 (Summer: March to May), S-3 (Rainy: June-August) and S-4 (Autumn: September-October).

\section{Age at first calving (AFC)}

The data were classified into three different groups according to the age at first calving. AFC within a range of mean \pm 1 SD was considered group-2 (A-2), >1 SD group-3 (A-3) and $<1$ SD as group-1 (A-1).

\section{Statistical analysis}

For statistical analysis, SPSS software programme (SPSS, 2013) version 22.0 was used. Mixed model analysis was carried out to study the effects of non-genetic factors on FFLMY, FL305MY and different monthly test day (TD) milk yield $\left(6^{\text {th }}, 36^{\text {th }}, \ldots ., 306^{\text {th }}\right)$ records of first lactation crossbred cattle data. The following models were used:

$$
Y_{i j k l}=m+A_{i}+B_{j}+C_{k}+e_{i j k l}
$$

where,

$Y_{i j k l}=$ FFLMY/ FL305MY/ TD milk yields of the $i^{\text {th }}$ individual of $k^{\text {th }}$ sire in $i^{\text {th }}$ age group and $j^{\text {th }}$ season

$m=$ Population mean

$A_{i}=$ Fixed effect of $i^{\text {th }}$ age at first calving ( $i=1$ to 3 )

$B_{j}=$ Fixed effect of $j^{\text {th }}$ season of calving ( $j=1$ to 4$)$

$C_{k}=$ Random effect of $k^{\text {th }}$ sire $(k=1$ to 89$)$

$e_{i j k}=$ Random error, assumed to be normally and independently distributed with mean zero and constant variance i.e. $\operatorname{NID}\left(0, \sigma^{2} e\right)$

The statistical significance of various fixed effects was determined by ' $F$ ' test. For significant effects, the differences between pairs of levels of effects were tested by Tukey's HSD (Honest Significant Difference) test.

\section{RESULTS AND DISCUSSION}

\section{Averages of different first lactation milk yield traits}

The least squares means along with their standard errors (S.E.) for first lactation monthly test day milk yields (TD) have been presented in Table 3. Perusal of the table showed that the highest weekly test day milk yield was observed in TD-2 $(15.65 \mathrm{~kg})$ and the lowest was observed in TD$11(10.28 \mathrm{~kg})$. In general, the monthly test day milk yield increased till TD-2 and thereafter a gradual decline was noticed till the end of lactation. Similar findings were also reported by Dongre et al. (2013) and they found highest milk yield in fortnightly TD-3 ( $36^{\text {th }}$ day) in Sahiwal cattle $(8.58 \mathrm{~kg})$. Thorat and Thombre (2019) also reported peak yield around $6^{\text {th }}$ week (43 ${ }^{\text {rd }}$ day) of lactation in Holstein Friesian $\times$ Deoni crossbred (Holdeo) cattle $(7.52 \mathrm{~kg})$.

The average FL305MY in the present study was $3818.17 \pm 103.26 \mathrm{~kg}$ (Table 2). Singh and Gurnani (2004) reported average FL305MY as $3,173 \pm 82 \mathrm{~kg}$ and $2616 \pm 82 \mathrm{~kg}$, respectively in Karan-Fries and Karan-Swiss 
crossbred cattle. Dongre et al. (2013) reported average FL305MY as $2005.28 \pm 36.17 \mathrm{~kg}$ in Sahiwal cattle. The average FFLMY in the present study was $4979.60 \pm 184.45$ $\mathrm{kg}$ (Table 2). Singh et al. (2006) reported average FFLMY as $3064.74 \pm 49.40 \mathrm{~kg}$ in $\mathrm{HF} \times$ Sahiwal crossbred cattle whereas Mandal et al. (2013) reported the average FFLMY as $2881.35 \pm 124.34 \mathrm{~kg}$ in crossbred Jersey cattle. The higher yield in the present study could be due to higher inheritance of Holstein Friesian blood in the herd.

Table 1: Least squares analysis of variance (mean squares only) for individual monthly test day milk yields, first lactation 305day (FL305DMY) and first full lactation (FFLDMY) milk yields in crossbred cattle

\begin{tabular}{llll}
\hline Traits & AFC groups & Season & Sire \\
\hline d.f. & 2 & 3 & 88 \\
TD1 & 37.867 & $197.284^{*}$ & $28.734^{*}$ \\
TD2 & 50.037 & $320.783^{*}$ & $33.158^{*}$ \\
TD3 & 6.401 & $279.972^{*}$ & $27.816^{*}$ \\
TD4 & 18.418 & $363.429^{*}$ & $32.807^{*}$ \\
TD5 & 19.307 & $326.053^{*}$ & $32.988^{*}$ \\
TD6 & 4.767 & $168.586^{*}$ & $28.523^{*}$ \\
TD7 & 2.701 & $80.963^{*}$ & $22.797^{* *}$ \\
TD8 & 11.717 & $66.992^{*}$ & $17.697^{* *}$ \\
TD9 & 6.242 & $74.801^{*}$ & 17.626 \\
TD10 & 14.079 & $73.690^{*}$ & 18.324 \\
TD11 & 17.144 & $69.061^{*}$ & 16.802 \\
FL305DMY & 816310.599 & 1624287.009 & $1607818.903^{* *}$ \\
FFLDMY & $17058089.652^{*}$ & 966064.014 & 4291118.505 \\
\hline
\end{tabular}

* significant at $1 \%(\mathrm{p} \leq 0.01) ;{ }^{* *}$ significant at $5 \%(\mathrm{p} \leq 0.05)$.

Table 2: Least squares means $(\mathrm{kg})$ of first lactation 305-day (FL305DMY) and first full lactation (FFLDMY) milk yields in crossbred cattle

\begin{tabular}{llll}
\hline & $\begin{array}{l}\text { No of } \\
\text { observations }\end{array}$ & $\begin{array}{l}\text { FL305DMY } \\
\text { Mean } \pm \text { SE }(\mathbf{k g})\end{array}$ & $\begin{array}{l}\text { FFLDMY } \\
\text { Mean } \pm \text { SE }(\mathbf{k g})\end{array}$ \\
Overall & 466 & $3818.17 \pm 103.26$ & $4979.60 \pm 184.45$ \\
S-1 & 173 & $3924.67^{\mathrm{ab}} \pm 125.32$ & $5021.80 \pm 223.86$ \\
S-2 & 123 & $3691.04^{\mathrm{ab}} \pm 136.25$ & $5063.72 \pm 243.37$ \\
S-3 & 108 & $3704.96^{\mathrm{a}} \pm 139.65$ & $4825.07 \pm 249.46$ \\
S-4 & 62 & $3952.00^{\mathrm{b}} \pm 185.11$ & $5007.81 \pm 330.64$ \\
A-1 & 50 & $3726.33 \pm 185.19$ & $5341.26^{\mathrm{b}} \pm 330.80$ \\
A-2 & 360 & $3753.63 \pm 100.52$ & $4490.94^{\mathrm{a}} \pm 179.55$ \\
A-3 & 56 & $3974.54 \pm 174.93$ & $5106.59^{\mathrm{ab}} \pm 312.46$ \\
\hline
\end{tabular}

Means with different superscripts within a column differ significantly.

\section{Non-genetic factors affecting different first lactation milk yield traits}

\section{Season of calving}

The effect of season of calving was highly significant $(\mathrm{P} \leq 0.01)$ on all the monthly test-day milk yields (Table 1$)$. The result was in almost conformity with results obtained by Dongre et al. (2011) in Sahiwal cattle and Thorat and Thombre (2019) in Holdeo cattle. The least square means along with their standard errors for season of calving affecting monthly test day milk yields are presented in Table 3 .

Overall, non-significant effect of season of calving was observed for FFLMY and FL305MY. However, there was significant difference between rainy and autumn calvers. Manoj et al. (2012) also reported non-significant effect of season of calving on FL305MY in Sahiwal cattle. However, Ratwan et al. (2016) reported significant effect of season on FL305MY in Jersey crossbred cattle. Jadhav and Khan (1995) in Holstein Friesian $\times$ Sahiwal cows and Varaprasad et al. (2013) in Jersey $\times$ Sahiwal cows reported non-significant effect of season on FLMY.

\section{Age at first calving}

The effects of different groups of age at first calving on monthly test day milk yields was non- significant. However, Dongre et al. (2011) reported significant $(\mathrm{P} \leq 0.05)$ effect of AFC groups on weekly TD4, TD5, TD7, TD8, TD9, TD11, TD12, TD14, TD16, TD19, TD21, TD23 and TD36 and non-significant effect was observed on remaining test days milk yields. Thorat and Thombre (2019) reported significant $(\mathrm{P}<0.01)$ variation due to age at first calving groups and non-significant in rest of the weekly test day milk yields in Holdeo cattle.

For FFLMYs, the effect of AFC was significant $(\mathrm{P}<$ 0.01 ); whereas it was non-significant for FL305MY in the present study. Wondifraw et al. (2013) and Mandal et al. (2013) also reported non-significant effect of AFC on 305 days milk yield in $\mathrm{HF} \times$ Deoni cattle and Jersey crossbred cattle, respectively. Mandal et al. (2013) also reported non-significant effect of age group on first lactation total milk yield in crossbred cattle. 
Table 3: Least squares means ( $\mathrm{kg}$ ) of different test-day milk yields in crossbred cattle

\begin{tabular}{lllllllll}
\hline Test days & Overall & S-1 & S-2 & S-3 & S-4 & A-1 & A-2 & A-3 \\
\hline TD-1 & $12.05 \pm 0.42$ & $13.69^{\mathrm{a}} \pm 0.51$ & $13.30^{\mathrm{a}} \pm 0.55$ & $10.58^{\mathrm{b}} \pm 0.57$ & $10.63^{\mathrm{b}} \pm 0.73$ & $10.96 \pm 0.74$ & $12.45 \pm 0.40$ & $12.74 \pm 0.72$ \\
TD-2 & $15.65 \pm 0.42$ & $18.19^{\mathrm{a}} \pm 0.51$ & $16.16^{\mathrm{b}} \pm 0.55$ & $13.64^{\mathrm{d}} \pm 0.58$ & $14.59^{\mathrm{c}} \pm 0.73$ & $14.35 \pm 0.74$ & $15.94 \pm 0.41$ & $16.65 \pm 0.72$ \\
TD-3 & $15.38 \pm 0.44$ & $17.74^{\mathrm{a}} \pm 0.53$ & $15.24^{\mathrm{b}} \pm 0.57$ & $13.38^{\mathrm{c}} \pm 0.61$ & $15.15^{\mathrm{b}} \pm 0.76$ & $15.04 \pm 0.77$ & $15.23 \pm 0.43$ & $15.86 \pm 0.76$ \\
TD-4 & $14.44 \pm 0.43$ & $16.81^{\mathrm{a}} \pm 0.52$ & $13.52^{\mathrm{b}} \pm 0.56$ & $12.16^{\mathrm{c}} \pm 0.59$ & $15.29^{\mathrm{a}} \pm 0.74$ & $13.81 \pm 0.75$ & $14.25 \pm 0.42$ & $15.27 \pm 0.74$ \\
TD-5 & $13.79 \pm 0.41$ & $15.73^{\mathrm{a}} \pm 0.49$ & $12.12^{\mathrm{b}} \pm 0.54$ & $12.02^{\mathrm{b}} \pm 0.56$ & $15.30^{\mathrm{a}} \pm 0.71$ & $13.49 \pm 0.72$ & $13.35 \pm 0.39$ & $14.53 \pm 0.71$ \\
TD-6 & $12.88 \pm 0.40$ & $13.61^{\mathrm{b}} \pm 0.48$ & $11.32^{\mathrm{c}} \pm 0.53$ & $11.80^{\mathrm{c}} \pm 0.54$ & $14.79^{\mathrm{a}} \pm 0.69$ & $12.56 \pm 0.69$ & $12.79 \pm 0.38$ & $13.29 \pm 0.68$ \\
TD-7 & $12.27 \pm 0.42$ & $11.97^{\mathrm{b}} \pm 0.51$ & $10.78^{\mathrm{c}} \pm 0.56$ & $12.86^{\mathrm{ab}} \pm 0.57$ & $13.46^{\mathrm{a}} \pm 0.74$ & $12.12 \pm 0.73$ & $12.47 \pm 0.41$ & $12.21 \pm 0.73$ \\
TD-8 & $11.83 \pm 0.37$ & $11.05^{\mathrm{b}} \pm 0.44$ & $10.82^{\mathrm{b}} \pm 0.49$ & $12.84^{\mathrm{a}} \pm 0.51$ & $12.62^{\mathrm{a}} \pm 0.66$ & $11.27^{\mathrm{b}} \pm 0.65$ & $11.72^{\mathrm{b}} \pm 0.36$ & $12.51^{\mathrm{a}} \pm 0.65$ \\
TD-9 & $10.85 \pm 0.42$ & $9.54^{\mathrm{b}} \pm 0.49$ & $11.03^{\mathrm{a}} \pm 0.54$ & $11.93^{\mathrm{a}} \pm 0.60$ & $10.92^{\mathrm{ab}} \pm 0.74$ & $10.37 \pm 0.73$ & $10.99 \pm 0.41$ & $11.20 \pm 0.73$ \\
TD-10 & $10.64 \pm 0.45$ & $9.34^{\mathrm{b}} \pm 0.53$ & $11.43^{\mathrm{a}} \pm 0.59$ & $11.50^{\mathrm{a}} \pm 0.64$ & $10.30^{\mathrm{ab}} \pm 0.82$ & $10.19 \pm 0.80$ & $10.32 \pm 0.43$ & $11.43 \pm 0.78$ \\
TD-11 & $10.28 \pm 0.50$ & $9.26^{\mathrm{b}} \pm 0.60$ & $11.75^{\mathrm{a}} \pm 0.66$ & $10.86^{\mathrm{ab}} \pm 0.73$ & $9.25^{\mathrm{b}} \pm 0.99$ & $10.79 \pm 0.89$ & $9.65 \pm 0.47$ & $10.39 \pm 0.90$ \\
\hline
\end{tabular}

Means with different superscripts within a row differ significantly.

\section{Sire effect}

Highly Significant $(\mathrm{p} \leq 0.01)$ effect of sire was observed for early TDs (TD-1 to TD-6), significant ( $\mathrm{p} \leq 0.05$ ) effect for the mid lactation TDs (TD-7 \& TD-8) and non-significant for rest of the test days. The sire effect was significant $(p \leq 0.05)$ for FL305MY whereas it was non-significant for FFLMY. Singh and Gurnani (2004) reported a significant $(\mathrm{P}<0.01)$ effect of sire on FL305MY in Karan Fries and Karan Swiss cattle. In Jersey crossbred, Ratwan et al. (2016) reported that sire had significant influence on FL305MY. In contrary to present study, Ratwan et al. (2016) reported significant influence of sire on total lactation milk yield (TLMY).

\section{CONCLUSION}

The monthly test-day milk yields were significantly influenced by season of calving. Significant influence of environmental components on milk production traits elucidates the importance of non-genetic parameters in breeding programmes for genetic improvement of crossbred cattle through selection. The effect of sire was significant for most of test-day milk yields suggesting the use of superior sires for improvement of milk production traits in dairy cattle.

\section{REFERENCES}

BAHS. 2019. Basic Animal Husbandry and Fisheries Statistics. Department of Animal Husbandry, Dairying \& Fisheries. Ministry of Agriculture, Govt. of India.
Dohare, A.K., Singh, B., Verma, M.R., Perme, B., Sharma, V.B., Gupta, N. and Kshandakar, S. 2014. Comparison of standard lactation curve models using fortnightly milk records in Frieswal cattle. Vet. World, 7(10): 831-834.

Dongre, V.B., Gandhi, R.S., Singh, A., Raja, T.V. and Singh, R.K. 2011. Effect of non-genetic factors on weekly test day milk yields and first lactation traits in Sahiwal cattle. Indian J. Anim. Res., 45(2):139-142.

Dongre, V.B., Gandhi, R.S., Singh, A., Sachdeva, G.K., Singh, R.K. and Gupta, A. 2013. Influence of non-genetic factors on fortnightly test day milk yields and first lactation 305 day milk yield in Sahiwal cattle. Indian J. Anim. Res., 47(2): 181183.

Jadhav, A. and Khan, F.H. 1995. Genetic and non-genetic factors affecting first lactation yield in Holstein $\times$ Sahiwal crossbreds. Indian J. Dairy Sci., 48: 251-252.

Mandal, A., Roy, P.K., Ghosh, M.K., Chatterjee, A. and Das, S.K. 2013. Genetic and environmental effects on first lactation traits of Jersey crossbred cattle in an organized herd of eastern India. Indian J. Dairy Sci., 66(2): 130-133.

Manoj, M., Gandhi, R.S, Raja, T.V., Singh, A. and Sachdeva, G.K. 2012. Effect of non-genetic factors on first lactation production and reproduction performance in Sahiwal cattle. Indian J. Dairy Sci., 65(3): 264-265.

Ratwan, P., Mandal, A., Kumar, M., Kumar, A. and Chakravarty A.K. 2016. Genetic analysis of lactation traits in Jersey crossbred cattle. Indian J. Dairy Sci., 69(2): 1-4.

Singh, M.K. and Gurnani, M. 2004. Performance evaluation of Karan Fries and Karan Swiss cattle under closed breeding system. Asian-Australas J. Anim. Sci., 17(1): 1-6. 
Singh, N.P., Yadav, M.C., Kushwaha, B.P. et al. 2006. Factors affecting milk production efficiency traits in Holstein $\times$ Sahiwal crosses. Indian J. Dairy Sci., 59(3): 172-176.

Thorat, B.N. and Thombre, B.M. 2019. Effect of non-genetic factors on weekly test day milk yield records in Holdeo cattle of Marathwada region. Indian J. Anim. Res., 53(6): 837-842.
Varaprasad, A.R., Raghunandan, T., Kumar, M.K. and Prakash, M.G. 2013. Studies on the productive performance of Jersey $\times$ Sahiwal cows in Chittoor district of Andhra Pradesh. African J. Agric. Res., 8(14): 1200-1203.

Wondifraw, Z., Thombre, B.M. and Bainwad, D.V.2013. Effect of non-genetic factors on milk production of Holstein Friesian $\times$ Deoni crossbred cows. Int. J. Livest. Prod., 4(7): 106-112. 
